\title{
The effect of chronic kidney disease on the urine proteome in the domestic cat (Felis catus)
}

E. Ferlizza ${ }^{a}$, A. Campos ${ }^{\text {b }}$, A. Neagu ${ }^{a}$, A. Cuoghi ${ }^{\text {c }}$, E. Bellei ${ }^{\text {c }}$, E. Monari ${ }^{c}$ F. Dondi ${ }^{\text {a }}$, A.M. Almeida d, G. Isani ${ }^{\mathrm{a}, *}$

${ }^{a}$ Department of Veterinary Medical Sciences, Alma Mater Studiorum-University of Bologna, Ozzano, Bologna, Italy.

${ }^{b}$ Interdisciplinary Centre of Marine and Environmental Research, University of Porto, Porto, Portugal

${ }^{c}$ Department of Diagnostic, Clinical and Public Health Medicine, University of Modena and Reggio Emilia, Modena, Italy

${ }^{d}$ CIISA - Interdisciplinary Research Centre of Animal Health, Faculty of Veterinary Medicine of the University of Lisbon, Lisbon, Portugal; IICT - Tropical Research Institute, Lisbon, Portugal, ITQB/UNL - Chemical and Biological Technologies Institute of the New University of Lisbon, Oeiras, Portugal and IBET - Technological and Experimental Biology Institute, Oeiras, Portugal.

* Corresponding author: Tel.: +39 0512097019.

E-mail address: gloria.isani@unibo.it (G. Isani). 


\section{Abstract}

Chronic kidney disease (CKD) is a major cause of mortality in cats, but sensitive and specific biomarkers for early prediction and monitoring of CKD are currently lacking. The present study aimed to apply proteomic techniques to map the urine proteome of the healthy cat and compare it with the proteome of cats with CKD. Urine samples were collected by cystocentesis from 23 healthy young cats and 17 cats with CKD. One-dimensional sodium-dodecyl-sulfate polyacrylamide gel electrophoresis (1D-SDS-PAGE) was conducted on 4-12\% gels. Two-dimensional electrophoresis (2DE) was applied to pooled urine samples from healthy cats $(n=4)$ and from cats with CKD $(n=4)$. Sixteen protein bands and 36 spots were cut, trypsin-digested and identified by mass spectrometry.

\section{D-SDS-PAGE yielded an overall view of the protein profile and the separation of $32 \pm 6$ protein} bands in the urine of healthy cats, while CKD cats showed significantly fewer bands $(P<0.01) .2-\mathrm{DE}$ was essential in fractionation of the complex urine proteome, producing a reference map that included 20 proteins. Cauxin was the most abundant protein in urine of healthy cats. Several protease inhibitors and transport proteins that derive from plasma were also identified, including alpha-2-macroglobulin, albumin, transferrin, haemopexin and haptoglobin. There was differential expression of 27 spots between healthy and CKD samples $(P<0.05)$ and 13 proteins were unambiguously identified. In particular, increased expression of retinol-binding protein, cystatin $\mathrm{M}$ and apolipoprotein-H associated with decreased expression of uromodulin and cauxin confirmed tubular damage in CKD cats suggesting that these proteins are candidate biomarkers.

Keywords: Biomarkers; Cat; Nephropathy; Proteinuria; Electrophoresis 


\section{Introduction}

Chronic Kidney Disease (CKD) is the most common renal disease of cats. Its prevalence is estimated at $1-3 \%$ in the general feline population, reaching 50\% in geriatric cats (Polzin, 2011; Bartges, 2012). Most cats with CKD caused by chronic tubulointerstitial nephritis have insignificant proteinuria (urinary protein to creatinine ratio, UPC $<0.2$ ). However, the minority of cats, particularly with advanced CKD, could be borderline (UPC $0.2-0.4$ ) or overtly proteinuric (UPC > 0.4), due to a more severe tubular and glomerular involvement. It is well known that proteinuria itself could promote further renal damage and CKD progression. However, the mechanism by which these excess proteins induce renal injury is still not entirely understood (Bartges, 2012).

(1)

Sensitive and specific biomarkers for early prediction and monitoring of CKD in cats are currently lacking. Quantitative methods for the detection of proteinuria, (urinary protein and urinary albumin to creatinine ratios; UPC and UAC, respectively) are used to evaluate the severity of renal involvement but offer no information on its aetiology or on composition of the urine proteome (Tesch, 2010). In addition, cauxin, a $70 \mathrm{kDa}$ protein secreted physiologically by the tubule in cats, can interfere with the assessment of proteinuria (Mischke, 2011; Miyazaki et al., 2011).

Urine is considered an ideal source of clinical biomarkers as it can be obtained repeatedly and noninvasively in sufficient amounts. High-resolution electrophoresis coupled with mass spectrometry (MS) allows fractionation and identification of the complex urine proteome and can therefore provide important information not only on kidney function but also on general health status. Over the last few years, large-scale proteomics have been extensively applied in human medicine, first to define the protein urine map and then to search for novel biomarkers of pathologies, including CKD (Candiano et al., 2010; He et al., 2012). In veterinary medicine, the application of proteomics techniques is still 

.

limited, but recently there have been significant efforts to study the urine proteome in dogs (Nabity et al., 2011; Schaefer et al., 2011; Brandt et al., 2014; Miller et al., 2014), and in cats to a lesser extent (Lemberger et al., 2011; Jepson et al., 2013). The many applications of proteomics have been recently reviewed (Almeida et al., 2015).

77

The aim of the present work was to produce a comprehensive characterization of the urine proteome of the healthy cats (Felis catus) and to compare it with the proteome in CKD patients. Ultimately we aimed to identify putative biomarkers of nephropathy to be used for detection of CKD or other renal diseases.

\section{Material and methods}

\section{Animal selection, sample collection and preparation}

The study used privately owned cats divided into two experimental groups. The healthy group was comprised of entire cats presented to a veterinary teaching hospital for neutering. Only animals considered healthy on the basis of history and physical examination and with no history of urinary tract disease were included. The diseased group was comprised of cats with CKD diagnosed on the basis of history, clinical signs, and clinicopathological and imaging results, according to Bartges (2012). Cats had to have (1) clinical findings of CKD, (2) persistent pathological renal proteinuria based on the urine protein to creatinine ratio, assessed and confirmed over a two-month period (UPC >0.2), and (3) a serum creatinine concentration $\geq 1.60 \mathrm{mg} / \mathrm{dL}$ and urine specific gravity (USG) $<1.035$.

CKD cats were staged according to the International Renal Interest Society (IRIS ${ }^{1}$ ) CKD guidelines. Upon arrival, all cats were subjected to a physical examination and routine laboratory tests,

\footnotetext{
${ }^{1}$ See: http://www.iris-kidney.com/guidelines/
} 
96

including complete blood count, serum chemistry and complete urinalysis with UPC and urine culture. Five millilitres of urine were collected from each animal by ultrasound-guided cystocentesis. After centrifugation at $1,500 \mathrm{~g}$ for $10 \mathrm{~min}$, supernatants were immediately stored at $-80^{\circ} \mathrm{C}$.

\section{Urine protein to creatinine ratio}

Urine total proteins and creatinine were determined using commercial kits (Urinary/CSF Protein, OSR6170, and Creatinine OSR6178, Olympus/Beckman Coulter) on an automated chemistry analyzer (AU 400, Olympus/Beckman Coulter). The UPC was calculated using the following formula:

$\mathrm{UPC}=$ urine protein $(\mathrm{mg} / \mathrm{dL}) /$ urine creatinine $(\mathrm{mg} / \mathrm{dL})$.

\section{One-dimensional gel electrophoresis (1D-SDS-PAGE)}

Urine proteins were separated using the electrophoresis NuPAGE system (Thermo Fisher Scientific) on $4-12 \%$ polyacrylamide gel in 2-( $N$-morpholino) ethanesulfonic acid buffer with sodiumdodecyl-sulfate (SDS) (Thermo Fisher Scientific). Two micrograms of protein for each sample were loaded. The gels were stained with SilverQuest (Thermo Fisher Scientific). After staining, each gel was digitalized and its pherogram was obtained using GelAnalyzer 2010 software ${ }^{2}$.

To evaluate differences between genders, two pools were prepared by collecting and mixing 20 $\mu \mathrm{g}$ of proteins from each healthy male $(n=8)$ and female $(n=15)$ sample. The pools were concentrated by Vivaspin500 spin columns (Sartorius Stedim Biotech) with a molecular weight (MW) cut-off of 3 $\mathrm{kDa}$ and separated by 1D-SDS-PAGE with the protocol reported above, with the exception of 3-(N-

\footnotetext{
${ }^{2}$ See: http://www.gelanalyzer.com/
} 
118 morpholino)propanesulfonic acid buffer and Coomassie blue staining (PageBlu protein staining 119 solution; Thermo Fisher Scientific) compatible with mass spectrometry analysis.

Two-dimensional gel electrophoresis $(2-D E)$

Urine samples from four healthy and four CKD cats were selected for 2-DE. To concentrate and desalt samples, $150 \mu \mathrm{g}$ of protein for each sample were precipitated with trichloroacetic acid to a final concentration of $10 \%$ in gentle shaking for $1 \mathrm{~h}$ and then centrifuged at $15,000 \mathrm{~g}$ for $30 \mathrm{~min}$ at $4{ }^{\circ} \mathrm{C}$. The protein pellets were washed three times with cold absolute acetone, air-dried and dissolved in a rehydration buffer containing $7 \mathrm{M}$ urea, $2 \mathrm{M}$ thiourea, 4\% 3-[(3-cholamidopropyl) dimethylammonio]1-propanesulfonate (CHAPS), $65 \mathrm{mM}$ dithiothreitol (DTT) and $0.8 \%$ resolytes (pH 3-10) before loading onto immobilized $\mathrm{pH}$ gradient (IPG) strips (non-linear $\mathrm{pH}$ gradient 3-10, $17 \mathrm{~cm}$ long) al. (2013). was run at $24 \mathrm{~mA}$ per gel for $6 \mathrm{~h}$ in Protean II XL (BioRad) in running buffer containing 25mM Tris,

Carvalho et al., (2014).

Protein identification by mass spectrometry

Protein bands and spots were excised manually from the gels and subjected to in-gel tryptic digestion as previously described (Bellei et al., 2013). After digestion, the peptides were analyzed by a 
142 Nano LC-CHIP-MS system (ESI-Q-TOF 6520, Agilent Technologies). Data were acquired in data-

143 dependent MS/MS mode in which, for each cycle, the three most abundant multiply charged peptides $144\left(2^{+}\right.$to $\left.4^{+}\right)$, above an absorbance threshold of 200 in the MS scan $(\mathrm{m} / \mathrm{z}$ full scan acquisition range from 145100 to 1700$)$, were selected for $\mathrm{MS} / \mathrm{MS}(\mathrm{m} / \mathrm{z}$ tandem mass spectrum acquisition range from 50 to 146 1700). Each peptide was selected twice and then dynamically excluded for 0.1 min. Raw mass 147 spectrometry data were processed with MassHunter Qualitative Analysis B.05.00 software to obtain the 148 Mascot generic files for database searching using the following parameters: deisotope, Absolute Height $149 \geq 10$, Relative Height $\geq 0.1 \%$ of largest peak.

Statistical analysis

Data were analyzed with statistical software (MedCalc Statistical Software version 12.7.5) and $<0.05$ as a significant probability.

Animal experimentation disclosure

The study was approved by our Institutional Scientific Ethical Committee for Animal Testing

(approval number 8-72-2012; date of approval 01 October 2012). AMA holds a FELASA grade C certificate enabling the design and conduction of animal experimentation under EU law.

Results

Animal selection and UPC

Out of the 44 entire domestic shorthair cats selected for the healthy group, 21 were excluded due to inadequate USG (<1.035), UPC >0.2, a urinalysis abnormality (glucosuria, haematuria, 
166 haemoglobinuria) or an active sediment ( $>5$ white blood cells per high power field or bacteriuria). The 167 remaining 23 cats (8 males, 15 females) were included in the study as the healthy group. The median 168 age was 24 months (6-168) and median UPC was $0.11(0.06-0.19)$.

Seventeen cats ( 5 neutered females, 8 neutered males and 4 entire males) were included in the

CKD group. CKD cats were significantly older with a median age of $168(60-240 ; P<0.01)$ and had a significantly increased UPC value (median $0.9 ; 0.25-6.5)$ than healthy cats $(P<0.01)$. All urine samples had inactive sediment and were negative on urine culture. Serum biochemistry and urinalysis data are reported in Table 1.

175

1D-SDS-PAGE

177

Representative gels and pherograms from healthy and CKD cats are shown in Fig. 1. We separated $32 \pm 6$ protein bands in the urine of healthy cats. The majority had a molecular weight (MW) of between 10 and $80 \mathrm{kDa}$. The CKD group had a greater inter-individual variability and typical tubular and $2 b$ ). samples $(n=16)$ were excised from the gel for MS identification (Fig. 3).

187 
Fig. 4 reports representative 2-D gels obtained from healthy (Fig. 4a) and CKD entire cats (Fig.

4b). Serum biochemistry and urinalysis data are reported in Table 2. Of the 66 spots detected, 27 showed differential expression $(P<0.05)$ between healthy and CKD samples; in particular, 18 spots were overrepresented in the CKD group and nine spots were increased in healthy animals. The remaining 39 spots were common and had similar expression levels. The nine most abundant common spots and the 27 differentially expressed spots were excised from the gels for MS identification.

\section{Protein identification by mass spectrometry}

From the 16 bands excised from 1-D gels, 14 proteins were identified (Table 3). Of the 36 2-DE spots analysed, 20 yielded significant results by MS, allowing the successful identification of 13 different proteins (Figs. 4a and b; Table 3). Albumin, cauxin, haemopexin and alpha-1 microglobulin precursor/bikunin (AMBP) were identified in spots characterized by different MW and/or isoelectric point. Seven proteins identified in 1-D gel were confirmed by 2-DE, namely uromodulin, albumin, transferrin, cauxin, haptoglobin, retinol binding protein (RBP) and immunoglobulin $\mathrm{K}$ light chain be functionally classified as transport (25\%), immune and cellular response (30\%), protein metabolism (25\%), and cellular communication and growth (15\%) (Fig. 5a). Most of the identified proteins were classified as extracellular (75\%) (Fig. 5b). were overrepresented in CKD samples, while alpha-2-macroglobulin (A2M), uromodulin, cauxin, inter-alpha-trypsin inhibitor heavy chain (ITIH4), pro-epidermal growth factor (EGF), angiotensinconverting enzyme (ACE2) and perlecan were underrepresented (Table 4). Examples of differentially 
212 expressed spots are reported in Fig. 4c. The other proteins did not show significant differences between 213 groups.

214

\section{Discussion}

The first aim of our research was to characterize the urine proteome in healthy cats and establish the proteome reference map. 1-D-SDS-PAGE yielded an overall view of the protein profile and resulted in a useful diagnostic tool that could help clinicians in qualitative evaluation of proteinuria. 2-DE was essential in fractionation of the complex urine proteome producing a reference map that included 20 proteins derived from either plasma ultrafiltration or kidney secretion, in accordance with data reported in humans (Adachi et al., 2006; Candiano et al., 2010; He et al., 2012) and dogs (Nabity et al., 2011; Brandt et al., 2014).

The most abundant protein was cauxin, a serine esterase produced by healthy tubular cells, specifically excreted in urine of cats and probably involved in the synthesis of feline pheromone (Miyazaki et al., 2006). Most of the other proteins identified were involved in protein metabolism, immune response and transport. Regarding protein metabolism, we found several protease inhibitors (A2M, A1AT, ITIH4) that may play an important role in protecting the kidney from proteolytic damage. Among the proteins involved in immune and cellular defence response, we identified protein AMPB, IgK and uromodulin. In contrast to dogs (Nabity et al., 2011; Brandt et al., 2014; Miller et al., 2014) and humans (Lhotta, 2010), uromodulin is not the most abundant urine-specific protein in cats. plasma and have been identified as common components of urine also from healthy humans (Candiano 
could contradict the paradigm of glomerular selectivity that should be re-evaluated according to the findings of Candiano et al. (2010) and Brandt et al. (2014). However, a possible blood contamination of urine due to cystocentesis cannot be excluded. The remaining proteins, EGF, perlecan and fetuin-A, are involved in cell communication and growth. In particular, perlecan, a negatively charged proteoglycan of the glomerular filtration barrier, has also been identified in dog urine (Nabity et al., 2011).

Regarding the effect of CKD on the urine cat proteome, we identified 13 proteins differentially represented that could be studied as putative biomarkers of nephropathy (Table 4). Our inclusion criteria led to the selection of proteinuric late stage CKD patients and based on UPC values a severe glomerular involvement could be hypothesised. However, most of these differentially expressed proteins are indicative of tubular dysfunction (e.g. RBP, CYSM, uromodulin and cauxin).

Among the overrepresented proteins, RBP is a low MW protein belonging to the family of lipocalins and is involved in plasma retinol transport. An increase in RBP is considered a biomarker of tubulointerstitial damage in humans and a significant correlation between urinary RBP and kidney interstitial fibrosis was recently demonstrated in CKD patients (Pallet et al., 2014). Elevated RBP in case of tubular damage has also been reported in dogs (Smets et al., 2010; Nabity et al., 2011). On the basis of our results, RBP can be considered an appealing marker to diagnose and monitor CKD in cats, as previously suggested by van Hoek et al. (2008).

CYSM belongs to the cystatin family, a class of lysosomal cysteine protease inhibitors, and is considered a major regulator of epidermal cornification and desquamation (Brocklehurst and Philpott, 2013). To our knowledge, CYSM has never been found in urine, while an increase in the more widely 
studied cystatin $\mathrm{C}$ has been correlated with tubular dysfunction in humans, dogs (Monti et al., 2012) and cats (Ghys et al., 2014); further studies are needed to clarify the role of CYSM in urine.

Apo-H (beta-2-glycoprotein 1) is a single chain multifunctional apolipoprotein also expressed in kidney tubular epithelium and involved in clotting mechanisms and lipid metabolism (Klaerke et al., 1997). The increase in urinary Apo-H in diabetic patients has been proposed as a marker of tubular dysfunction (Lapsley et al., 1993), and recent studies focused on the increased levels of IgA anti-Apo$\mathrm{H}$ in CKD patients (Serrano et al., 2014); the role of this protein in cat urine is still unknown. The last two overrepresented proteins in CKD cats, namely CFAD and $\operatorname{IgK}$, are involved in the immune response. CFAD is a serine protease synthesized mainly by adipocytes and macrophages belonging to the alternative complement pathway. The only report of this protein in urine regards a significant increase in human patients with preeclampsia (Wang et al., 2014).

Among the underrepresented proteins, there were significant decreases in uromodulin, cauxin and perlecan. Uromodulin is a 95-kDa glycoprotein exclusively synthesized by the cells of the thick ascending limb. Its exact molecular function is still unknown, but it is thought to be a potent immunoregulatory protein: recent studies have hypothesized that uromodulin entering the renal interstitium through the damaged tubuli can stimulate the cells of the immune system causing inflammation and CKD progression (El-Achkar and $\mathrm{Wu}, 2012)$. The decrease in uromodulin was previously observed also in dogs affected by leishmaniasis (Buono et al., 2012), suggesting its use as a biomarker of renal damage in small animals.

2-DE was essential in obtaining the separation of albumin from cauxin, demonstrating a significant decrease of cauxin; however a possible influence of the entire/neutered status cannot be 
283

284

285

286

287

288

289

290

291

292

293

294

295

296

297

298

299

300

301

302

303

304

305

306

completely excluded. Though Jepson et al. (2010) showed a weak correlation between cauxin and the onset of azotemia, our data, according to Miyazaki et al. (2007), suggest that this protein could be a promising biomarker for the determination of tubular damage in CKD cats, particularly in entire males.

\section{compartment (Ebefors et al., 2011) and could also suggest glomerular involvement in cats affected by}

renal disease. The remaining underrepresented proteins are involved in protein metabolism or cellular defence and communication. In particular, the decrease in the protease inhibitors A2M and ITIH4 could indicate a role in the pathophysiology of CKD. In support of this mechanism, intensive protein degradation has also been reported to occur in the urine of humans with CKD (Mullen et al., 2011). This finding is in accordance with the increased protein fragmentation, especially of albumin, found in our study.

Although the proteomic approach we applied led to a preliminary feline urine proteome map and to the identification of new putative biomarkers of nephropathy, our study presented some limitations. To obtain samples with an adequate amount of proteins, we selected proteinuric cats with advanced stages of CKD. Although we excluded patients with possible primary glomerular involvement, we cannot state that all cats included in the study had the same underlying renal pathophysiological condition. Therefore, further studies are needed to confirm our results and to evaluate urine proteome also in non-proteinuric CKD cats. Moreover, the differences in age and neuter status between healthy and CKD cats could be considered minor limitations. In our study the agerelated changes should have been minimized by the selection of proteinuric cats with advanced stages of CKD and the neuter/entire influence reduced by the exclusion of borderline and proteinuric healthy male entire cats. 
308

309

310

311

312

313

314

315

316

317

318

319

320

321

322

323

324

325

326

327

328

329

\section{Conclusions}

Our work has produced a reference map of the normal urine proteome in cats and can be considered the starting point for future studies. Moreover, this is the first research linking of 13 differentially represented urine proteins with $\mathrm{CKD}$ in cats. The different amounts of uromodulin, cauxin, CFAD, Apo-H, RBP and CYSM confirm tubulointerstitial damage in CKD cats and suggest that these proteins are candidate biomarkers to be investigated further. Our data on the proteins most represented in the cat urine proteome and their changes in CKD could be useful in the advancement of research focused on the discovery of new biomarkers for later use in clinical practice. In particular, uromodulin, cauxin and perlecan, which are specifically secreted in urine, could help in the evaluation of feline renal function.

\section{Acknowledgements}

This study was supported by a grant from the University of Bologna (RFO) to GI. AMA is supported by grant SFRH/BPD/90916/2012 from Fundação para a Ciência e a Tecnologia (Lisbon, Portugal), AC by the contract work Ciência 2007 from FCT. AMA, AC, EF and GI are members of COST Action FA1002 - Proteomics in Farm Animals ${ }^{3}$ funded by the European Science Foundation and to whom networking support is acknowledged.

\footnotetext{
${ }^{3}$ See: www.cost-FAProteomics.org
} 


\section{References}

Adachi, J., Kumar, C., Zhang, Y., Olsen, V.J., Mann, M., 2006. The human urinary proteome contains more than 1500 proteins, including a large proportion of membrane proteins. Genome Biology 7 , R80.

Almeida, A.M., Bassols, A., Bendixen, E., Bhide, M., Ceciliani, F., Cristobal, S., Hollung, K., Lisacek, F., Mazzucchelli, G., McLaughlin M. et al., 2015. Invited review: advances in proteomics for animal and food sciences. Animal 9, 1-17.

Bartges, J.W., 2012. Chronic kidney disease in dogs and cats. Veterinary Clinics of North America: Small Animal Practice 42, 669-692.

Bellei, E., Monari, E., Cuoghi, A., Bergamini, S., Guerzoni, S., Ciccarese, M., Ozben, T., Tomasi, A., Pini, L.A., 2013. Discovery by a proteomic approach of possible early biomarkers of drug-induced nephrotoxicity in medication-overuse headache. The Journal of Headache and Pain 14, 6.

Bertoldi, C., Bellei, E., Pellacani, C., Ferrari, D., Lucchi, A., Cuoghi, A., Bergamini, S., Cortellini, P., Tomasi, A., Zaffe, D., et al., 2013. Non-bacterial protein expression in periodontal pockets by proteome analysis. Journal of Clinical Periodontology. 40, 573-582.

Brandt, L.E., Ehrhart, E.J., Scherman, H., Olver, C.S., Bohn, A.A., Prenni, J.E., 2014. Characterization of the canine urinary proteome. Veterinary Clinical Pathology 43, 193-205.

Brocklehurst, K., Philpott, M.P., 2013. Cysteine proteases: mode of action and role in epidermal differentiation. Cell and Tissue Research 351, 237-244.

Buono, A., Duque, J., Ferlizza, E., Zaragoza, C., Barrera, R., Isani, G., Dondi, F., 2012. Non-invasive diagnostic evaluation including qualitative proteinuria to detect an early renal damage in canine leishmaniasis. In: Proceedings of the European College of Veterinary Internal Medicine Companion Animal Congress, Maastricht, NL. Journal of Veterinary Internal Medicine 26, 15371538.

Campos, A., Puerto, M., Prieto, A., Cameán, A., Almeida, A.M., Coelho, A.V., Vasconcelos, V., 2013. Protein extraction and two-dimensional gel electrophoresis of proteins in the marine mussel Mytilus galloprovincialis: an important tool for protein expression studies, food quality and safety assessment. Journal of the Science of Food and Agricolture 93, 1779-1787.

Candiano, G., Santucci, L., Petretto, A., Bruschi, M., Dimuccio, V., Urbani, A., Bagnasco, S., Ghiggeri, G.M., 2010. 2D-electrophoresis and the urine proteome map: where do we stand? Journal of Proteomics 73, 829-844.

Cruz De Carvalho, R., Bernardes Da Silva, A., Soares, R., Almeida, A.M., Coelho, A.V., Marques Da Silva, J., Branquinho, C., 2014. Differential proteomics of dehydration and rehydration in bryophytes: evidence towards a common desiccation tolerance mechanism. Plant, Cell and Environment 37, 1499-1515. 
Ebefors, K., Granqvist, A., Ingelsten, M., Mölne, J., Haraldsson, B., Nyström, J., 2011. Role of glomerular proteoglycans in IgA nephropathy. PLoS ONE 6, e18575.

El-Achkar, T.M., Wu, X.R., 2012. Uromodulin in kidney injury: an instigator, bystander, or protector? American Journal of Kidney Disease 59, 452-61.

Ghys, L.F.E., Meyer, E., Paepe, D., Delanghe, J., Daminet, S., 2014. Analytical validation of a human particle-enhanced nephelometric assay for cystatin $\mathrm{C}$ measurement in feline serum and urine. Veterinary Clinical Pathology 43, 226-234.

He, W., Huang, C., Luo, G., Dal Prà, I., Feng, J., Chen, W., Ma, L., Wang, Y., Chen, X., Tan, J. et al., 2012. A stable panel comprising 18 urinary proteins in the human healthy population. Proteomics $12,1059-1072$.

Jepson, R.E., Syme, H.M., Markwell, P., Miyazaki, M., Yamashita, T., Elliott, J., 2010. Measurement of urinary cauxin in geriatric cats with variable plasma creatinine concentrations and proteinuria and evaluation of urine cauxin-to-creatinine concentration ratio as a predictor of developing azotemia. American Journal of Veterinary Research 71, 982-987.

Jepson, R., Coulton, G., Cowan, M., Markwell, P., Syme, H.M., Elliott, J., 2013. Evaluation of mass spectrometry of urinary proteins and peptides as biomarkers for cats at risk of developing azotemia. American Journal of Veterinary Research 74, 333-342.

Klaerke, D.A., Røjkjaer, R., Christensen, L., Schousboe, I., 1997. Identification of $\beta 2$-glycoprotein I as a membrane-associated protein in kidney: purification by calmodulin affinity chromatography. Biochimica et Biophysica Acta 1339, 203-216.

Lapsley, M., Flynn, F. V., Sansom, P.A., 1993. Beta 2-Glycoprotein-1 (apolipoprotein H) excretion and renal tubular malfunction in diabetic patients without clinical proteinuria. Journal of Clinical Pathology 46, 465-469.

Lemberger, S.I.K., Deeg, C.A., Hauck, S.M., Amann, B., Hirmer, S., Hartmann, K., Dorsch, R., 2011. Comparison of urine protein profiles in cats without urinary tract disease and cats with idiopathic cystitis, bacterial urinary tract infection, or urolithiasis. American Journal of Veterinary Research 72, 1407-1415.

Lhotta, K., 2010. Uromodulin and chronic kidney disease. Kidney and Blood Pressure Research 33, 393-398.

Miller, I., Preßlmayer-Hartler, A., Wait, R., Hummel, K., Sensi, C., Eberini, I., Razzazi-Fazeli, E., Gianazza, E., 2014. In between - Proteomics of dog biological fluids. Journal of Proteomics 106, $30-45$.

Mischke, R., 2011. Assessing proteinuria in the cat: an innovative tip. The Veterinary Journal 189, 243244. 
Miyazaki, M., Yamashita, T., Hosokawa, M., Taira, H., Suzuki, A., 2006. Species-, sex-, and agedependent urinary excretion of cauxin, a mammalian carboxylesterase. Comparative Biochemistry and Physiology Part B: Biochemistry and Molecular Biology 145, 270-277.

Miyazaki, M., Soeta, S., Yamagishi, N., Taira, H., Suzuki, A., Yamashita, T., 2007. Tubulointerstitial nephritis causes decreased renal expression and urinary excretion of cauxin, a major urinary protein of the domestic cat. Research in Veterinary Science 82, 76-79.

Miyazaki, M., Fujiwara, K., Suzuta, Y., Wakamatsu, N., Taira, H., Suzuki, A., Yamashita, T., 2011. Screening for proteinuria in cats using a conventional dipstick test after removal of cauxin from urine with a Lens culinaris agglutinin lectin tip. The Veterinary Journal 189, 312-317.

Monti, P., Benchekroun, G., Berlato, D., Archer, J., 2012. Initial evaluation of canine urinary cystatin C as a marker of renal tubular function. Journal of Small Animal Practice 53, 254-259.

Mullen, W., Delles, C., Mischak, H., 2011. Urinary proteomics in the assessment of chronic kidney disease. Current Opinion in Nephrology and Hypertension 20, 654-661.

Nabity, M.B., Lees, G.E., Dangott, L.J., Cianciolo, R., Suchodolski, J.S., Steiner, J.M., 2011. Proteomic analysis of urine from male dogs during early stages of tubulointerstitial injury in a canine model of progressive glomerular disease. Veterinary Clinical Pathology 40, 222-236.

Pallet, N., Chauvet, S., Chassé, J.-F., Vincent, M., Avillach, P., Levi, C., Meas-Yedid, V., Olivo-Marin, J.C., Nga-Matsogo, D., Beaune, P. et al., 2014. Urinary retinol binding protein is a marker of the extent of interstitial kidney fibrosis. PLoS ONE 9, e84708.

Polzin, D.J., 2011. Chronic kidney disease in small animals. Veterinary Clinics of North America: Small Animal Practice 41, 15-30.

Schaefer, H., Kohn, B., Schweigert, F.J., Raila, J., 2011. Quantitative and qualitative urine protein excretion in dogs with severe inflammatory response syndrome. Journal of Veterinary Internal Medicine 25, 1292-1297.

Serrano, M., Martínez-Flores, J.A., Castro, M.J., García, F., Lora, D., Pérez, D., Gonzalez, E., PazArtal, E., Morales, J.M., Serrano, A., 2014. Renal transplantation dramatically reduces IgA antibeta-2-glycoprotein I antibodies in patients with endstage renal disease. Journal of Immunology Research 2014, 641962.

Smets, P.M.Y., Meyer, E., Maddens, B.E.J., Duchateau, L., Daminet, S., 2010. Urinary markers in healthy young and aged dogs and dogs with chronic kidney disease. Journal of Veterinary Internal Medicine 24, 65-72.

Tesch, G.H., 2010. Review: serum and urine biomarkers of kidney disease: a pathophysiological perspective. Nephrology 15, 609-616.

Van Hoek, I., Daminet, S., Notebaert, S., Janssens, I., Meyer, E., 2008. Immunoassay of urinary retinol binding protein as a putative renal marker in cats. Journal of Immunological Methods 329, 208213. 
Wang, T., Zhou, R., Gao, L., Wang, Y., Song, C., Gong, Y., Jia, J., Xiong, W., Dai, L., Zhang, L., et al., 2014. Elevation of urinary adipsin in preeclampsia: correlation with urine protein concentration and the potential use for a rapid diagnostic test. Hypertension 64, 846-851. 


\section{Table 1}

476 Clinical data for cats affected by CKD $(n=17)$.

477

\begin{tabular}{|c|c|c|c|}
\hline Signalment & Mean \pm SD & $n$ & \\
\hline Age in months & $160 \pm 64$ & & \\
\hline Female (entire/neutered) & & $5(0 / 5)$ & \\
\hline Male (entire/neutered) & & $12(4 / 8)$ & \\
\hline Serum biochemistry & Mean \pm SD & $n(\%)<$ or $>$ RI & RI \\
\hline Total Proteins $(\mathrm{g} / \mathrm{dL})$ & $7.9 \pm 0.8$ & $6(35)>$ & $6.0-8.0$ \\
\hline Albumin (g/dL) & $3 \pm 0.4$ & $4(24)>$ & $2.1-3.3$ \\
\hline Creatinine (mg/dL) & $5.9 \pm 3.6$ & $17(100)>$ & $0.8-1.6$ \\
\hline Urea $(\mathrm{mg} / \mathrm{dL})$ & $264 \pm 148$ & $16(94)>$ & $15-60$ \\
\hline Phosphorus (mg/dL) & $9.5 \pm 5.7$ & $9(54)>$ & $2.9-8.3$ \\
\hline Urine biochemistry & Mean \pm SD & $n(\%)<$ or $>\mathrm{RI}$ & RI \\
\hline UPC & $1.29 \pm 1.52$ & $14(82)>$ & $<0.4$ \\
\hline USG & $1.018 \pm 0.012$ & $15(88)<$ & $>1.035^{1}$ \\
\hline IRIS Stage & & $n(\%)$ & \\
\hline II & & $4(24)$ & \\
\hline III & & $4(24)$ & \\
\hline IV & & $9(53)$ & \\
\hline Clinical signs & & $\mathrm{n}(\%)$ & \\
\hline Inappetence/anorexia & & $15(88)$ & \\
\hline Polyuria/polydipsia & & $11(65)$ & \\
\hline Depression & & $7(41)$ & \\
\hline Weight loss & & $4(24)$ & \\
\hline Abnormal renal palpation & & $3(18)$ & \\
\hline Oral lesions & & $3(18)$ & \\
\hline Vomiting & & $2(12)$ & \\
\hline Weakness & & $2(12)$ & \\
\hline Dehydration & & $2(12)$ & \\
\hline Diarrhoea & & $1(6)$ & \\
\hline Blindness & & 1(6) & \\
\hline
\end{tabular}

RI, reference interval; UPC, urine protein to creatinine ratio; USG, urine specific gravity.

${ }^{1}$ Considered as adequate USG in cats 
482 Table 2

483 Clinical data for healthy and CKD cats selected for 2-DE.

\begin{tabular}{|c|c|c|c|c|c|c|c|c|c|c|}
\hline & Gender & $\begin{array}{c}\text { Age } \\
\text { (months) }\end{array}$ & $\begin{array}{c}\mathrm{TP} \\
(\mathrm{g} / \mathrm{dL})\end{array}$ & $\begin{array}{l}\text { ALB } \\
(\mathrm{g} / \mathrm{dL})\end{array}$ & $\begin{array}{c}\text { Creatinine } \\
\text { (mg/dL) }\end{array}$ & $\begin{array}{c}\text { Urea } \\
(\mathrm{mg} / \mathrm{dL})\end{array}$ & $\begin{array}{c}\mathrm{P} \\
(\mathrm{mg} / \mathrm{dL})\end{array}$ & UPC & USG & $\begin{array}{l}\text { IRIS } \\
\text { stage }\end{array}$ \\
\hline RI & & & $6.0-8.0$ & $2.1-3.3$ & $0.8-1.6$ & $15-60$ & 2.9-8.3 & $<0.4$ & $>1.035^{1}$ & \\
\hline \multicolumn{11}{|c|}{ CKD } \\
\hline 1 & M & 96 & 6.35 & 2.35 & 1.76 & 97 & 4.9 & 0.50 & 1.020 & II \\
\hline 2 & $\mathrm{C}$ & 216 & 8 & 3 & 4.3 & 195 & 5.5 & 1.50 & 1.018 & III \\
\hline 3 & $\mathrm{C}$ & 160 & 8.8 & 2.65 & 5.23 & 401 & 18.3 & 6.30 & 1.022 & IV \\
\hline 4 & M & 170 & 9 & 2.8 & 8.9 & 474 & 17 & 3.50 & 1.014 & IV \\
\hline \multicolumn{11}{|c|}{ Healthy } \\
\hline 1 & $\mathrm{M}$ & 6 & 6.76 & 2.4 & 0.95 & 56 & 4.3 & 0.19 & 1048 & \\
\hline 2 & M & 24 & 7.12 & 3 & 1.35 & 43 & 3.2 & 0.13 & 1056 & \\
\hline 3 & $\mathrm{M}$ & 12 & 6.5 & 2.8 & 1.5 & 25 & 6.8 & 0.08 & 1072 & \\
\hline 4 & M & 6 & 7.6 & 2.9 & 1.24 & 50 & 5.4 & 0.14 & 1044 & \\
\hline
\end{tabular}

484

485

486

487

488

489

490

TP, serum total protein; ALB, serum albumin; P, serum phosphorus; UPC, urine protein to creatinine ratio; USG, urine specific gravity; RI, reference interval; $\mathrm{M}$, entire male; $\mathrm{C}$, neutered male.

${ }^{1}$ Considered as adequate USG in cats 
Proteins identified in cat urine by mass spectrometry.

\begin{tabular}{|c|c|c|c|c|c|c|c|c|c|}
\hline $\begin{array}{c}\text { Band }^{\mathrm{a}} \\
1-\mathrm{DE}\end{array}$ & Entry name ${ }^{b}$ & Protein full name & $\begin{array}{l}\mathrm{MW}^{\mathrm{c}} \\
(\mathrm{kDa})\end{array}$ & $\mathrm{pI}$ & Score $^{\mathrm{d}}$ & Pept. ${ }^{\mathrm{e}}$ & Seq. ${ }^{\mathrm{f}}$ & $\begin{array}{l}\text { Sign. } \\
\text { Seq. }{ }^{g}\end{array}$ & Identity ${ }^{h}$ \\
\hline 1 & TRFE_BOVIN & Serotransferrin & 79.9 & 6.75 & 88 & 15 & 7 & 3 & 73 \\
\hline \multirow{2}{*}{2} & EST5A_FELCA & Carboxylesterase 5A & 60.9 & 5.58 & 238 & 27 & 10 & 6 & 100 \\
\hline & ALBU_FELCA & Serum albumin & 70.6 & 5.46 & 135 & 21 & 8 & 6 & 100 \\
\hline \multirow{3}{*}{3} & ALBU_FELCA & Serum albumin & 70.6 & 5.46 & 346 & 37 & 16 & 10 & 100 \\
\hline & EST5A_FELCA & Carboxylesterase 5A & 60.9 & 5.58 & 41 & 8 & 4 & 2 & 100 \\
\hline & KV1_CANFA & Ig kappa chain V region GOM & 12.1 & 6.41 & 91 & 3 & 2 & 1 & 71 \\
\hline \multirow[t]{2}{*}{4} & IGLL5_HUMAN & $\begin{array}{l}\text { Immunoglobulin lambda-like } \\
\text { polypeptide } 5\end{array}$ & 23.4 & 9.08 & 66 & 11 & 1 & 1 & 79 \\
\hline & ALBU_FELCA & Serum albumin & 70.6 & 5.46 & 59 & 9 & 6 & 2 & 100 \\
\hline 5 & ALBU_FELCA & Serum albumin & 70.6 & 5.46 & 1340 & 115 & 34 & 25 & 100 \\
\hline 6 & RET4_HORSE & Retinol-binding protein 4 & 23.3 & 5.28 & 1121 & 42 & 6 & 4 & 93 \\
\hline 7 & CYTM_HUMAN & Cystatin-M & 16.5 & 7.0 & 71 & 3 & 2 & 1 & 79 \\
\hline \multirow{2}{*}{8} & A2MG_BOVIN & Alpha-2-macroglobulin & 168.9 & 5.71 & 121 & 9 & 4 & 1 & 75 \\
\hline & ALBU_FELCA & Serum albumin & 70.6 & 5.46 & 115 & 18 & 9 & 4 & 100 \\
\hline 9 & ITIH4_HUMAN & $\begin{array}{l}\text { Inter-alpha-trypsin inhibitor } \\
\text { heavy chain } \mathrm{H} 4\end{array}$ & 103.5 & 6.51 & 70 & 9 & 2 & 2 & 73 \\
\hline \multirow{3}{*}{10} & ACE2_FELCA & $\begin{array}{l}\text { Angiotensin-converting } \\
\text { enzyme } 2\end{array}$ & 93.1 & 5.64 & 178 & 15 & 6 & 5 & 100 \\
\hline & UROM_CANFA & Uromodulin & 72.9 & 4.94 & 112 & 20 & 4 & 4 & 86 \\
\hline & EGF_FELCA & Pro-epidermal growth factor & 137.3 & 5.8 & 83 & 13 & 7 & 4 & 100 \\
\hline \multirow{2}{*}{11} & ALBU_FELCA & Serum albumin & 70.6 & 5.46 & 147 & 24 & 11 & 7 & 100 \\
\hline & EST5A_FELCA & Carboxylesterase 5A & 60.9 & 5.58 & 145 & 20 & 8 & 2 & 100 \\
\hline \multirow{2}{*}{12} & HPT_CANFA & Haptoglobin & 36.9 & 5.72 & 80 & 27 & 8 & 6 & 90 \\
\hline & EST5A_FELCA & Carboxylesterase 5A & 60.9 & 5.58 & 102 & 16 & 7 & 3 & 100 \\
\hline 13 & IGLL5_HUMAN & $\begin{array}{l}\text { Immunoglobulin lambda-like } \\
\text { polypeptide } 5\end{array}$ & 23.4 & 9.08 & 115 & 16 & 1 & 1 & 100 \\
\hline \multirow{2}{*}{14} & EST5A_FELCA & Carboxylesterase 5A & 60.9 & 5.58 & 254 & 30 & 12 & 6 & 100 \\
\hline & TRFE_PIG & Serotransferrin & 78.9 & 6.93 & 71 & 19 & 7 & 4 & 74 \\
\hline \multirow{2}{*}{15} & ALBU_FELCA & Serum albumin & 70.6 & 5.46 & 532 & 53 & 22 & 17 & 100 \\
\hline & EST5A_FELCA & Carboxylesterase 5A & 60.9 & 5.58 & 439 & 68 & 16 & 9 & 100 \\
\hline \multirow{3}{*}{16} & ALBU_FELCA & Serum albumin & 70.6 & 5.46 & 5932 & 346 & 51 & 42 & 100 \\
\hline & EST5A_FELCA & Carboxylesterase 5A & 60.9 & 5.58 & 1941 & 157 & 24 & 23 & 100 \\
\hline & A1AT_CHLAE & Alpha-1-antitrypsin & 44.6 & 5.75 & 109 & 11 & 3 & 2 & 71 \\
\hline \multicolumn{10}{|l|}{$\begin{array}{l}\text { Spot }^{a} \\
2-D E\end{array}$} \\
\hline 1 & UROM_CANFA & Uromodulin & 72.9 & 4.94 & 130 & 36 & 6 & 3 & 86 \\
\hline 2 & ALBU_FELCA & Serum albumin & 70.6 & 5.46 & 2383 & 196 & 39 & 28 & 100 \\
\hline 3 & ALBU_FELCA & Serum albumin & 70.6 & 5.46 & 2133 & 208 & 35 & 29 & 100 \\
\hline 4 & EST5A_FELCA & Carboxylesterase 5A & 60.9 & 5.58 & 524 & 66 & 14 & 10 & 100 \\
\hline 5 & EST5A_FELCA & Carboxylesterase 5A & 60.9 & 5.58 & 447 & 89 & 14 & 10 & 100 \\
\hline
\end{tabular}




\begin{tabular}{cllccccccc}
6 & TRFE_PIG & Serotransferrin & 78.9 & 6.93 & 114 & 31 & 9 & 5 & 74 \\
7 & FETUA_HUMAN & Fetuin-A & 40.1 & 5.43 & 141 & 34 & 6 & 4 & 70 \\
8 & APOH_CANFA & Apolipoprotein H & 39.7 & 8.51 & 162 & 21 & 4 & 4 & 88 \\
9 & HPT_BOVIN & Haptoglobin & 45.6 & 7.83 & 72 & 6 & 2 & 2 & 78 \\
10 & AMBP_BOVIN & Protein AMBP & 40.1 & 7.81 & 141 & 5 & 1 & 1 & 78 \\
11 & AMBP_BOVIN & Protein AMBP & 40.1 & 7.81 & 150 & 6 & 1 & 1 & 78 \\
12 & AMBP_BOVIN & Protein AMBP & 40.1 & 7.81 & 274 & 11 & 1 & 1 & 78 \\
13 & PGBM_HUMAN & Perlecan & 479.3 & 6.06 & 134 & 19 & 3 & 2 & 91 \\
14 & HEMO_PONAB & Hemopexin & 52.3 & 6.44 & 73 & 25 & 3 & 1 & 83 \\
15 & HEMO_PONAB & Hemopexin & 52.3 & 6.44 & 97 & 25 & 3 & 1 & 83 \\
16 & ALBU_FELCA & Serum albumin & 70.6 & 5.46 & 1585 & 187 & 40 & 25 & 100 \\
17 & APOH_CANFA & Apolipoprotein H & 39.7 & 8.51 & 119 & 16 & 5 & 4 & 88 \\
18 & ALBU_FELCA & Serum albumin & 70.6 & 5.46 & 69 & 10 & 7 & 3 & 100 \\
& KV1_CANFA & Ig kappa chain V region GOM & 12.1 & 6.41 & 111 & 4 & 2 & 2 & 71 \\
19 & CFAD_PIG & Complement factor D & 28.3 & 6.59 & 54 & 9 & 2 & 2 & 86 \\
20 & RET4_HUMAN & Retinol-binding protein 4 & 23.3 & 5.76 & 167 & 27 & 8 & 3 & 94 \\
\hline
\end{tabular}

$494{ }^{a}$ Number of the identified band or spot as marked in Figs. 3 and 4, respectively.

$495{ }^{\mathrm{b}}$ Protein entry name from UniProt knowledge database.

$496 \quad{ }^{\mathrm{c}}$ Theoretical protein molecular weight.

$497{ }^{\mathrm{d}}$ The highest scores obtained with Mascot search engine.

$498{ }^{\mathrm{e}}$ Peptides: total number of peptides matching the identified proteins.

$499{ }^{f}$ Sequence: total number of sequences matching the identified proteins.

$500{ }^{\mathrm{g}}$ Significant Sequences: total number of significant sequences matching the identified proteins.

$501{ }^{\mathrm{h}}$ Percentage of identical amino acids between the identified protein and the respective cat protein. 


\section{Table 4}

504 Differentially expressed proteins identified by mass spectrometry (ESI-Q-TOF).

\begin{tabular}{|c|c|c|c|c|c|}
\hline $\begin{array}{l}\text { Band }^{\mathrm{a}} \\
1-\mathrm{DE}\end{array}$ & Entry name ${ }^{b}$ & Protein full name & $\begin{array}{l}\text { CKD vs. } \\
\text { healthy }{ }^{c}\end{array}$ & Molecular function ${ }^{\mathrm{d}}$ & Biological process ${ }^{\mathrm{e}}$ \\
\hline 6 & RET4_HUMAN & Retinol-binding protein 4 & Up & Transporter & Transport \\
\hline 7 & CYTM_HUMAN & Cystatin-M & Up & Protease inhibitor & Protein metabolism \\
\hline 8 & A2MG_BOVIN & Alpha-2-macroglobulin & Down & Protease inhibitor & Protein metabolism \\
\hline 9 & ITIH4_HUMAN & $\begin{array}{l}\text { Inter-alpha-trypsin } \\
\text { inhibitor heavy chain } \mathrm{H} 4\end{array}$ & Down & Protease inhibitor & Protein metabolism \\
\hline \multirow{3}{*}{10} & ACE2_FELCA & $\begin{array}{l}\text { Angiotensin-converting } \\
\text { enzyme } 2\end{array}$ & Down & $\begin{array}{l}\text { Protease- } \\
\text { carboxylpeptidase } \\
\text { activity }\end{array}$ & Protein metabolism \\
\hline & UROM_CANFA & Uromodulin & Down & Unknown & $\begin{array}{l}\text { Cellular defence } \\
\text { response }\end{array}$ \\
\hline & EGF_FELCA & $\begin{array}{l}\text { Pro-epidermal growth } \\
\text { factor }\end{array}$ & Down & Growth factor activity & $\begin{array}{l}\text { Cell communication; } \\
\text { Signal transduction }\end{array}$ \\
\hline \multicolumn{6}{|l|}{$\begin{array}{l}\text { Spot }^{\mathrm{a}} \\
2-\mathrm{DE}\end{array}$} \\
\hline 1 & UROM_CANFA & Uromodulin & Down & Unknown & $\begin{array}{l}\text { Cellular defence } \\
\text { response }\end{array}$ \\
\hline 2 & ALBU_FELCA & Albumin & Down & Transporter & Transport \\
\hline $4 ; 5$ & EST5A_FELCA & Carboxylesterase 5A & Down & $\begin{array}{l}\text { Protease-hydrolase } \\
\text { activity }\end{array}$ & Unknown \\
\hline $8 ; 17$ & APOH_CANFA & Apolipoprotein $\mathrm{H}$ & Up & Transporter & Transport \\
\hline 13 & PGBM_HUMAN & Perlecan & Down & $\begin{array}{l}\text { Extracellular matrix } \\
\text { structural constituent }\end{array}$ & $\begin{array}{l}\text { cell } \\
\text { Growth/maintenance }\end{array}$ \\
\hline $16 ; 18$ & ALBU_FELCA & Albumin & Up & Transporter & Transport \\
\hline \multirow[t]{2}{*}{19} & KV1_CANFA & $\begin{array}{l}\text { Ig kappa chain } \mathrm{V} \text { region } \\
\text { GOM }\end{array}$ & Up & Antigen binding & Immune response \\
\hline & CFAD_PIG & Complement factor D & Up & Serine-type peptidase & Immune response \\
\hline 20 & RET4_HUMAN & Retinol-binding protein 4 & Up & Transporter & Transport \\
\hline
\end{tabular}

$506{ }^{a}$ Number of the identified band or spot as marked in Figs. 3 and 4 respectively.

$507 \quad{ }^{\mathrm{b}}$ Protein entry name from UniProt knowledge database.

$508{ }^{c}$ Significantly $(P<0.05)$ overrepresented (up) and underrepresented (down) proteins in CKD group respect to healthy.

$509{ }^{\mathrm{d}}$ Molecular function according to Gene Ontology and Human Reference Proteome Database.

$510{ }^{\mathrm{e}}$ Biological process according to Gene Ontology and Human Reference Proteome Database. 


\section{$512 \quad$ Figure legends}

514 Fig. 1. 1D-SDS-PAGE of cat urine proteins. Two micrograms of proteins were loaded and stained with 515 silver nitrate. Representative gel (lane 1, molecular weight marker; lanes 2-7, urine samples from CKD 516 cats; lanes 8-9, healthy urine samples) (A) and pherograms (B) are shown.

517 Fig. 2. Comparison of the number of protein bands between healthy and CKD cats. (A) Total number 518 of bands. (B) Number of bands with MW>100 kDa. Different lower cases indicate significant 519 differences $(P<0.01)$.

520 Fig. 3. 1D-SDS-PAGE of urine samples from healthy and CKD cats, stained with Coomassie Blue. 521 Lane 1, molecular weight marker; lanes 2-3, CKD urine samples; lanes 4-5, pools of urine from 522 healthy females and males respectively. Rectangles and numbers indicate the bands that have been cut 523 and identified by ESI-Q-TOF (Table 3).

524 Fig. 4. 2-DE of the urine proteome in healthy (A) and CKD (B) entire cats. White circles: spots with 525 significantly greater intensity in healthy than in CKD; black circles: spots with significantly greater intensity in CKD; white rectangles: common spots without significant differences. (C) Examples of important differentially expressed proteins.

Fig. 5. Classification of the proteins identified according to Gene Ontology and the Human Reference Proteome Database (HRPD). 
Figure1A

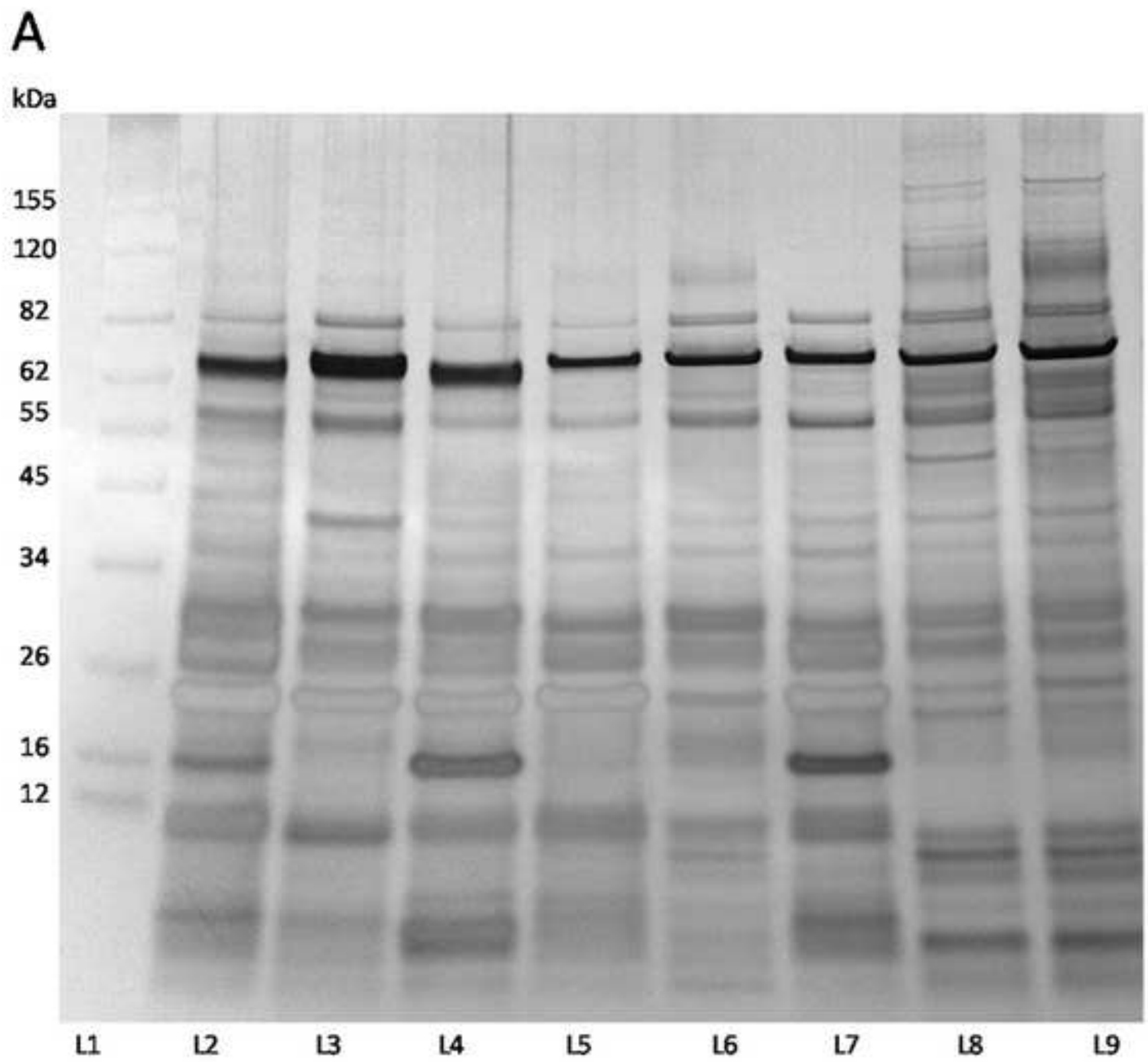



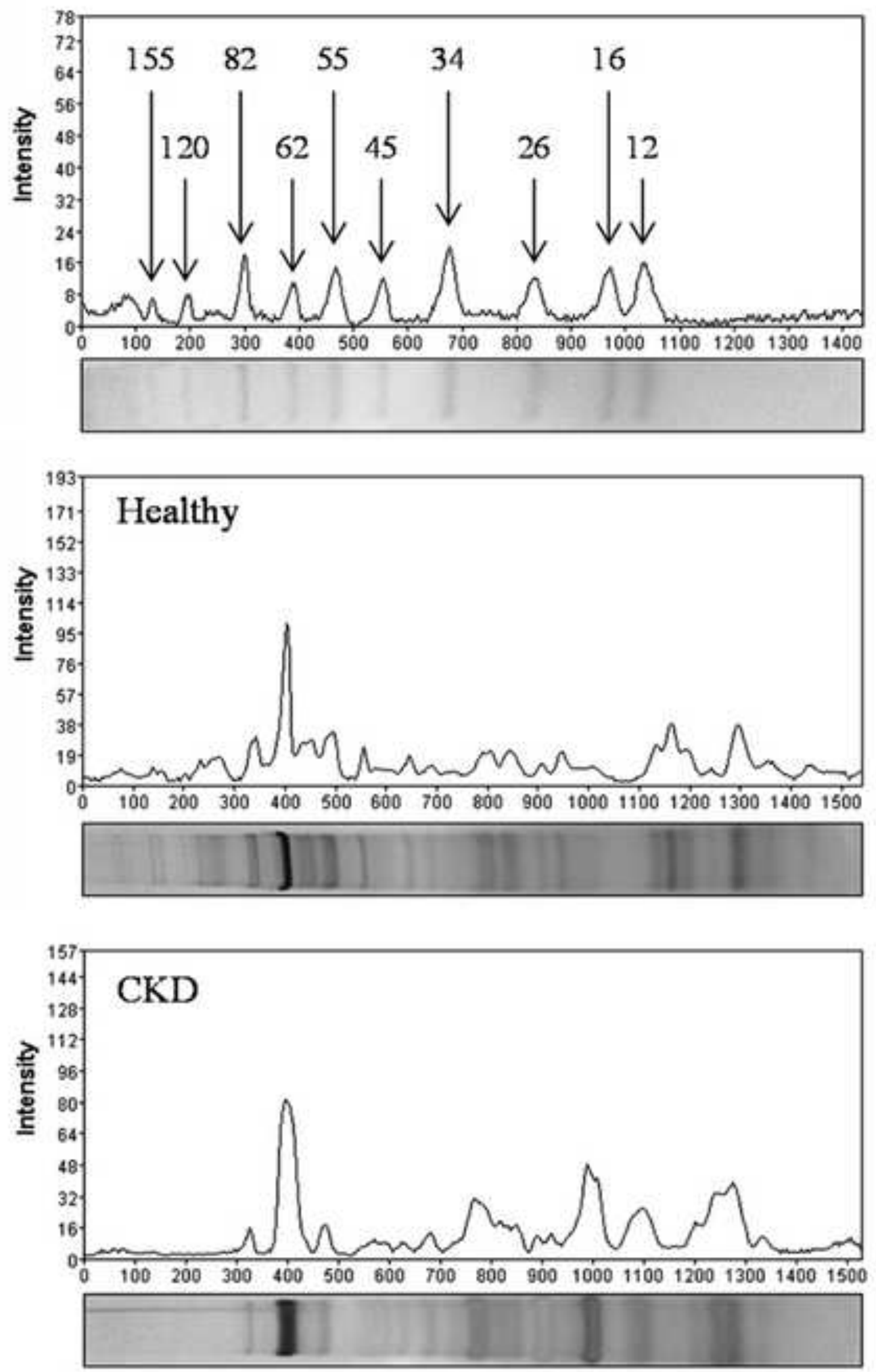
A

\section{Total number of bands}

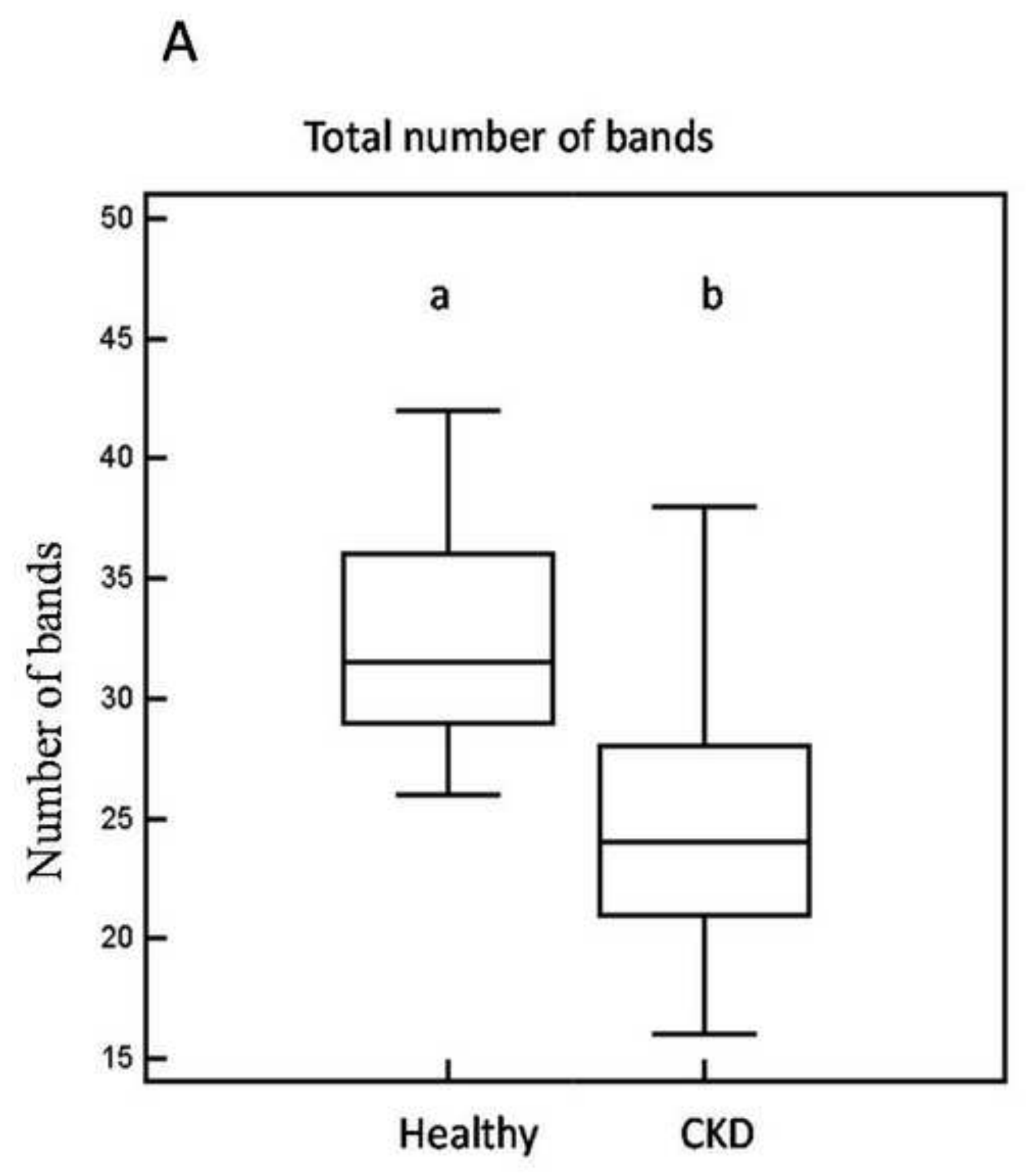

Figure2A

A

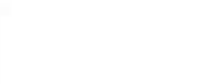


B

Number of bands MW>100kDa

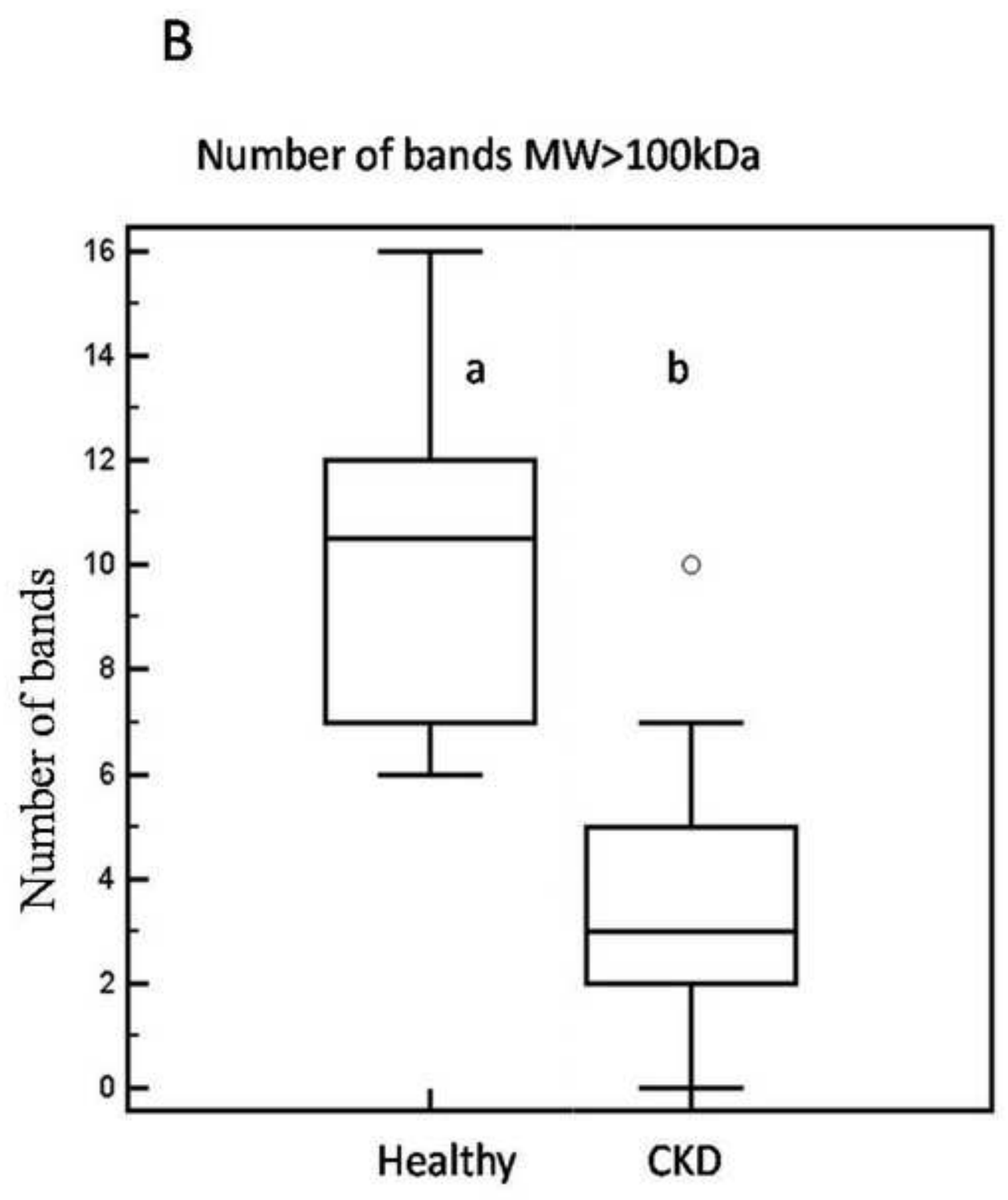

Figure2B 
kDa

165

115

81

61

54

42

32

24

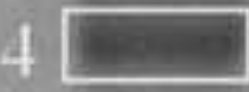

5
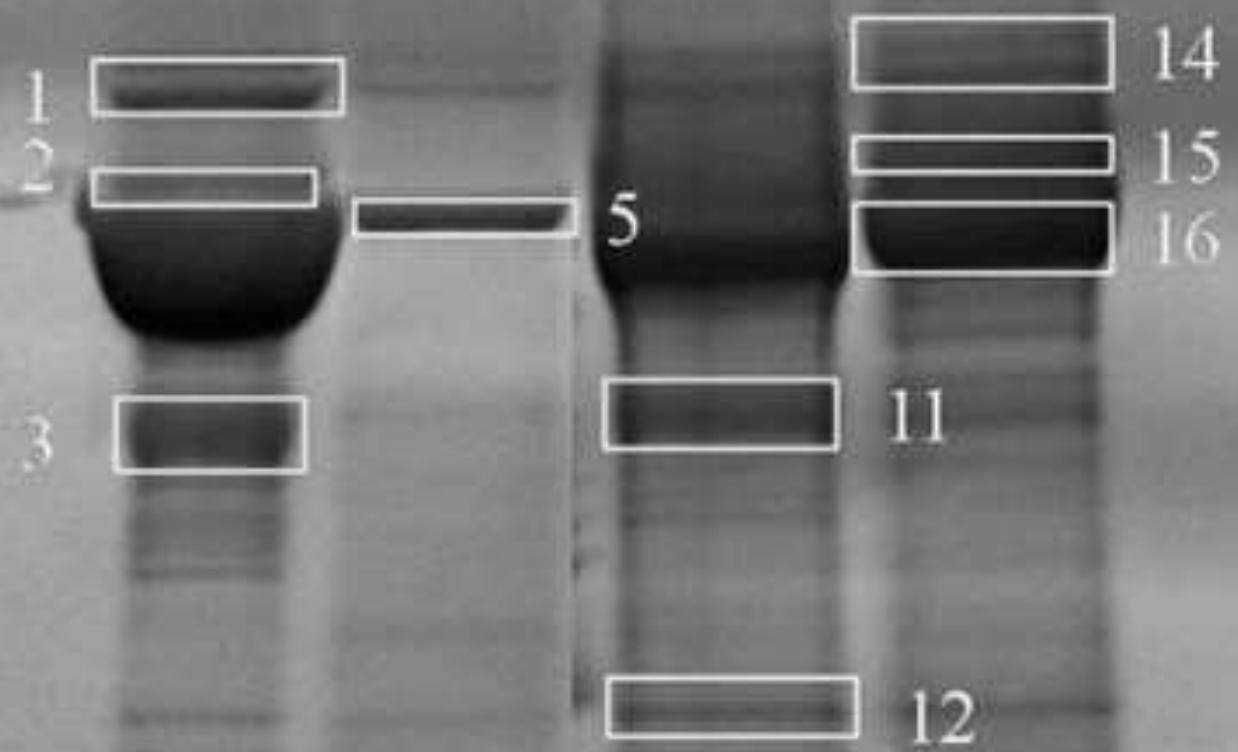

11
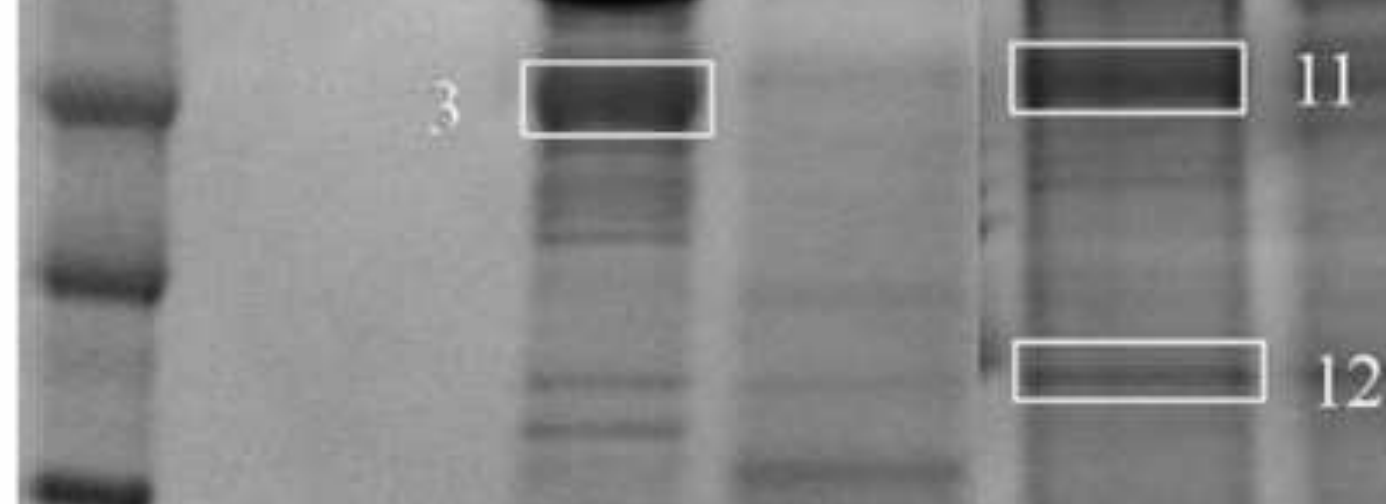

12

17

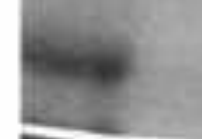

L1

L2

L3

L4

L5 
A

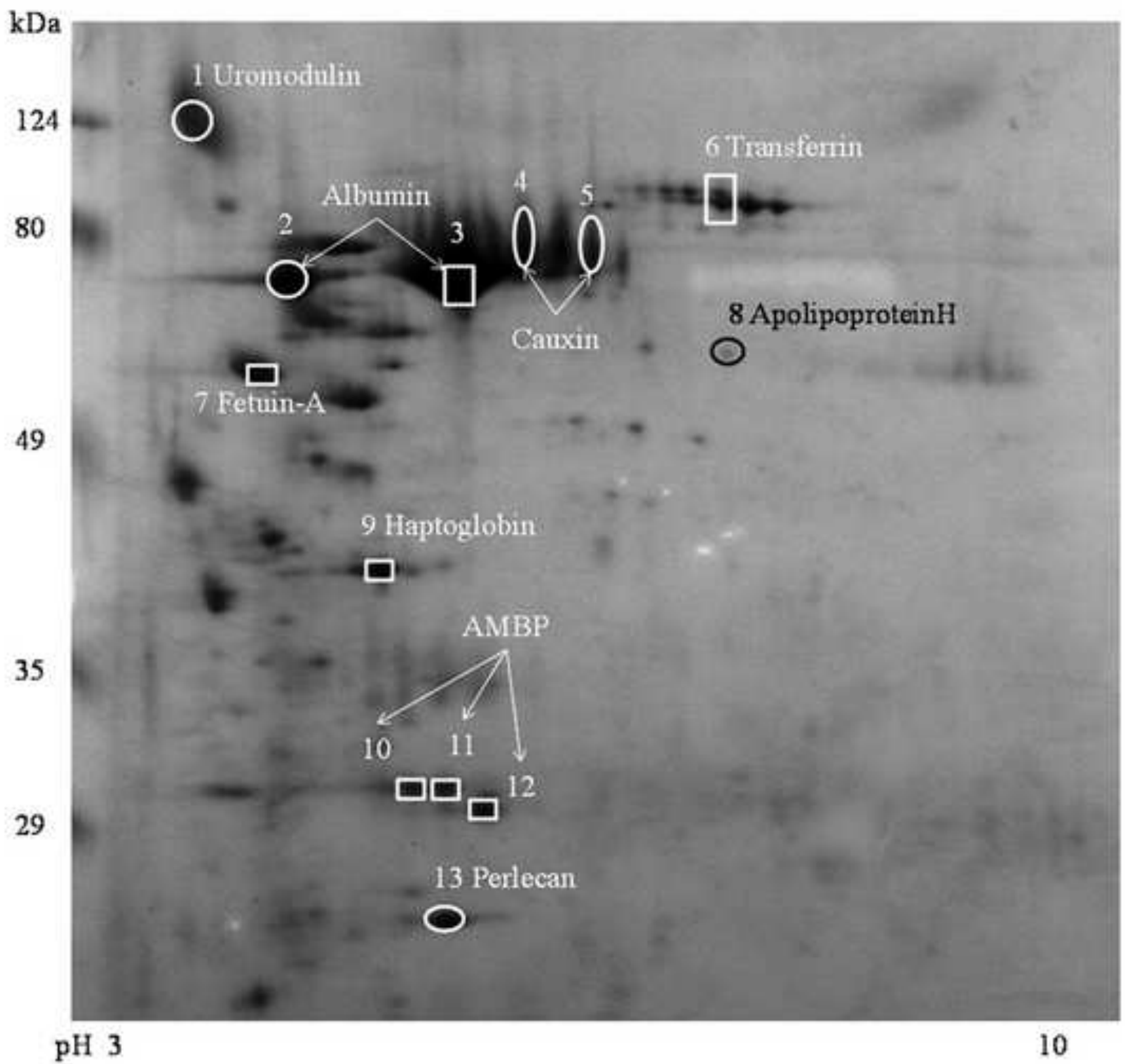




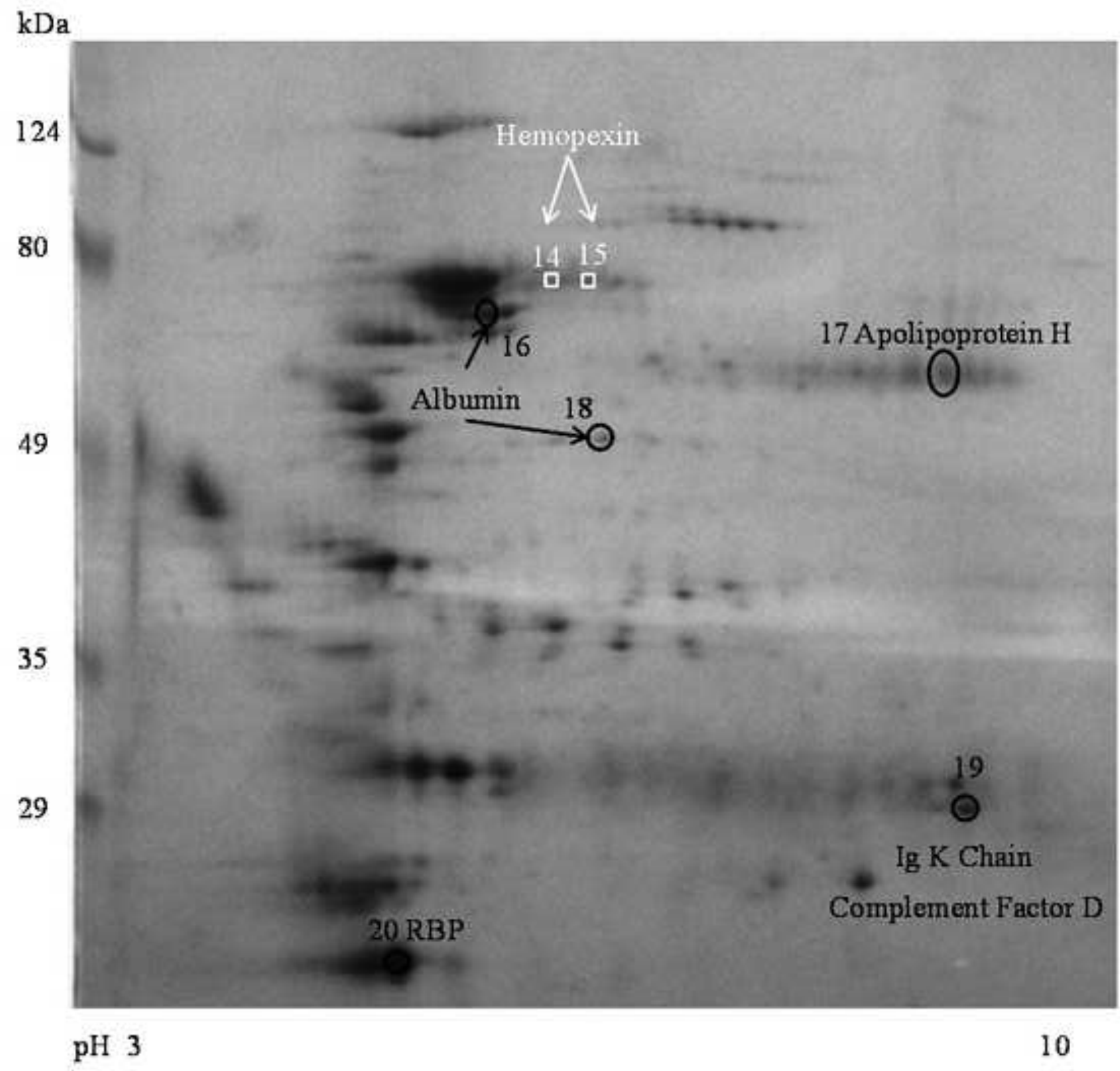


C

Spot 13: perlecan
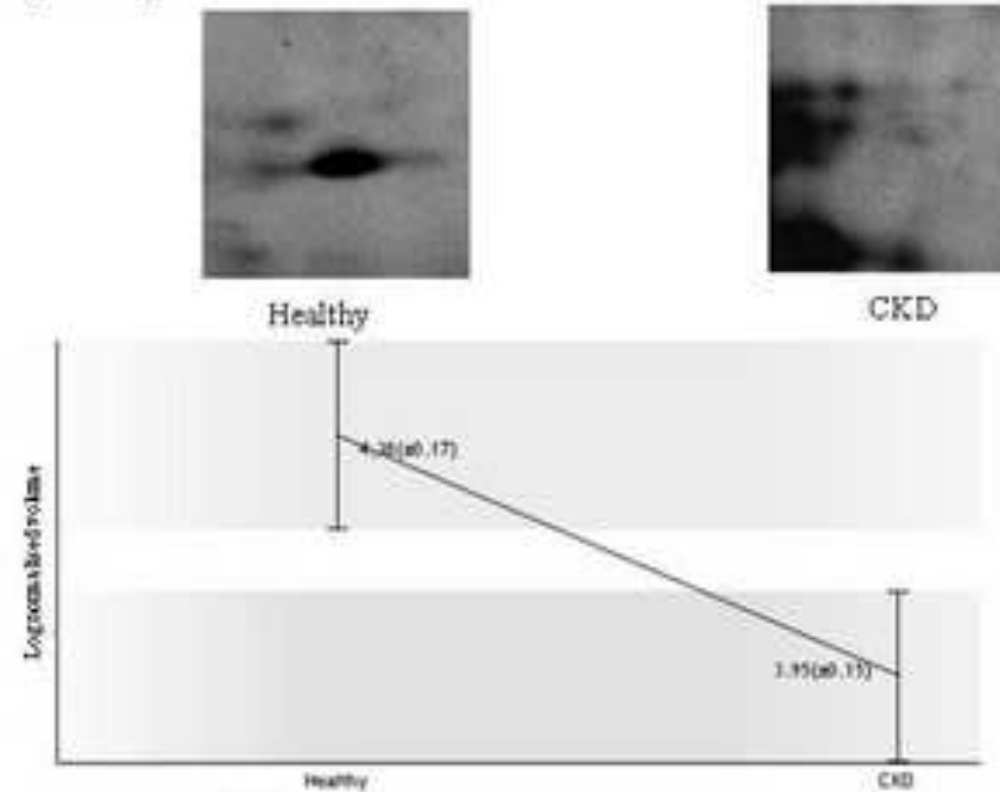

Spct 1. uromodulin

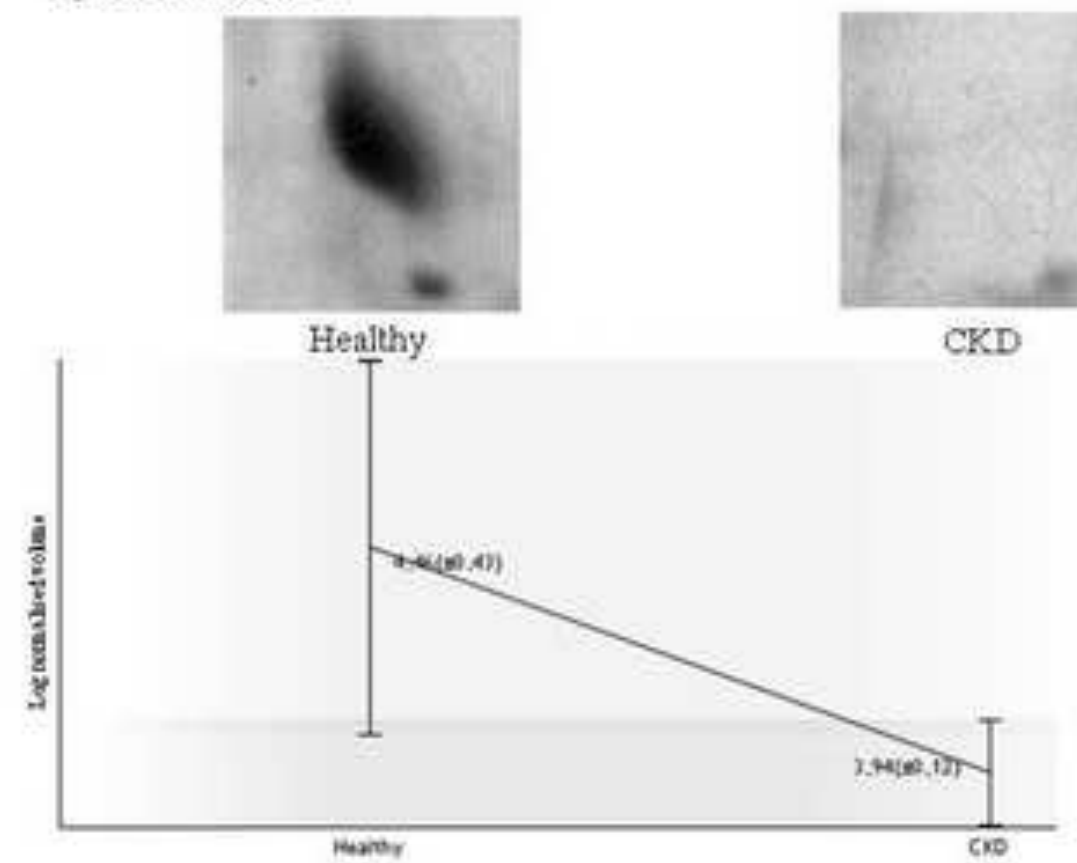

Sp $\alpha 20$ retinol binding protein
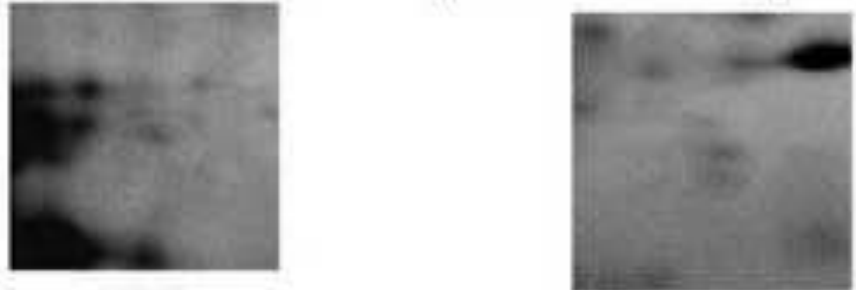

Healthy

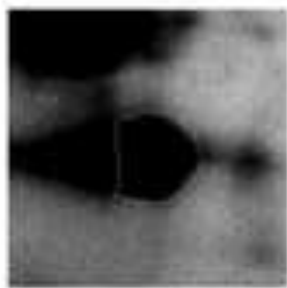

CKD

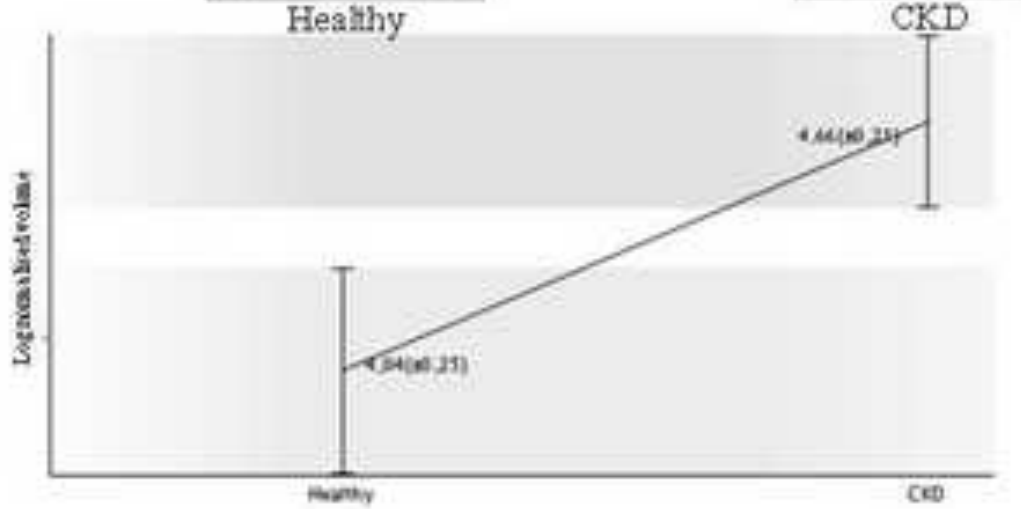

Spot 18: apolipoproten- $\mathrm{H}$
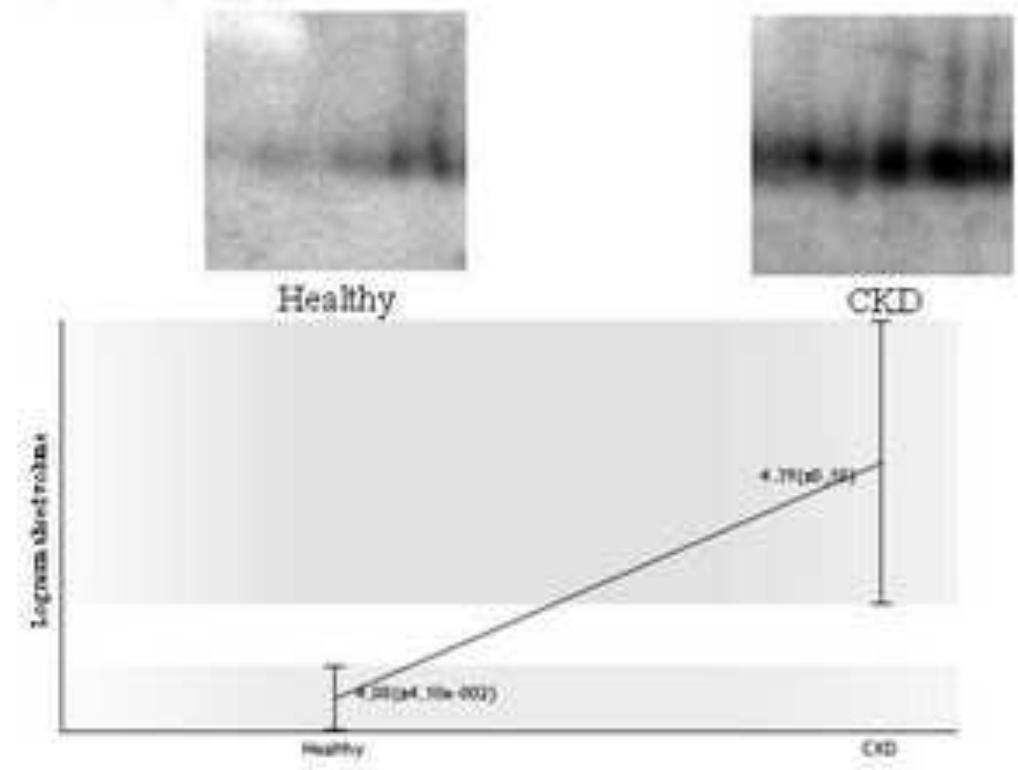


\section{Biological Process}
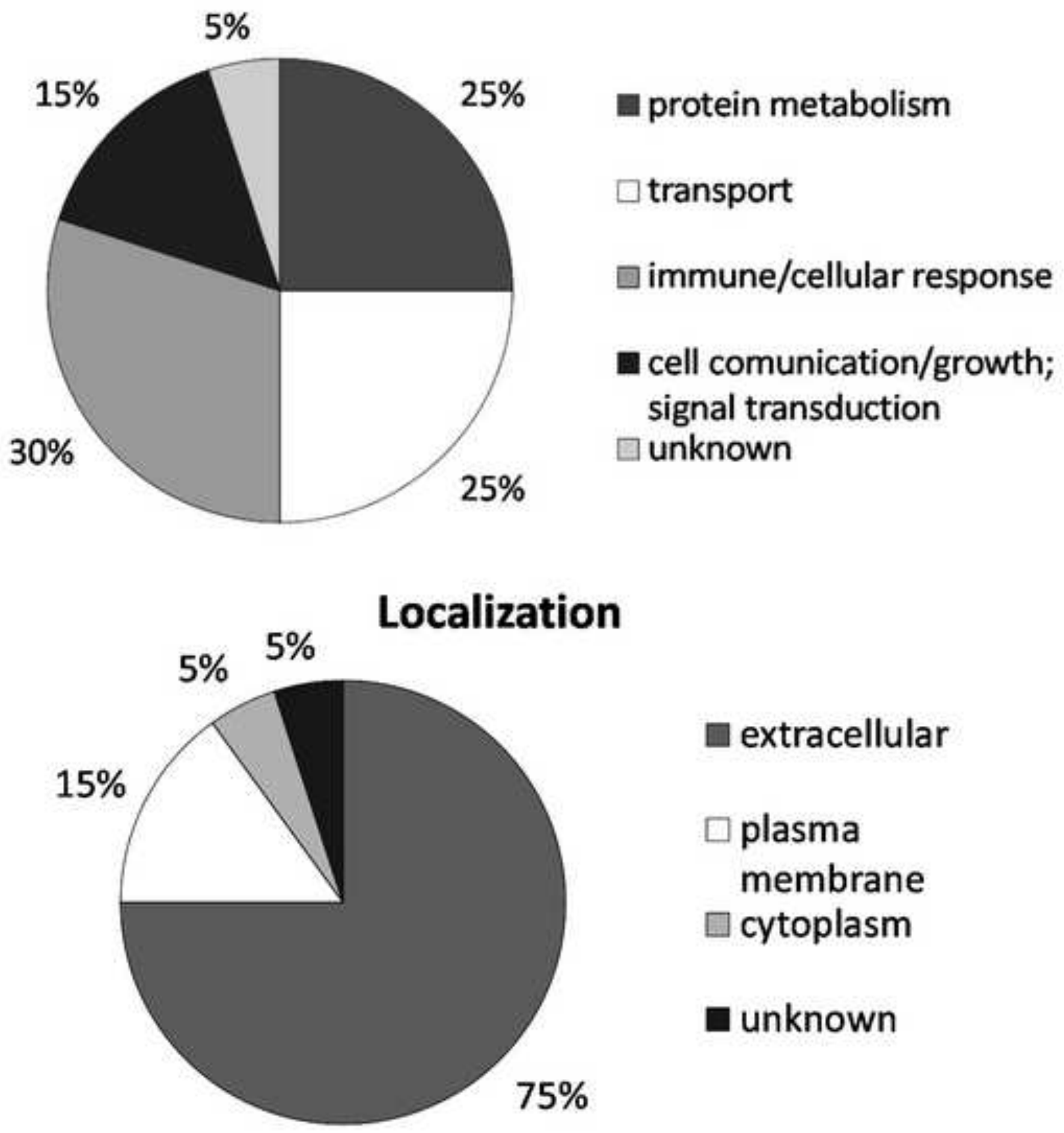

— extracellular

$\square$ plasma membrane

$\square$ cytoplasm

unknown 